\title{
STUDY ON THE CREEP BEHAVIOUR OF NAPPA UPPER PIG LEATHER
}

\author{
Keyong TANG ${ }^{1 *}$, Weilin $\mathrm{LI}^{1}$, Fang WANG ${ }^{1}$, Jie LIU $^{1}$, Mădălina G. ALBU ${ }^{2}$
}

${ }^{1}$ College of Materials Science and Engineering, Zhengzhou University, Henan 450001, P. R. China,

keyongtangzzu@yahoo.com

${ }^{2}$ INCDTP - Division: Leather and Footwear Research Institute, Collagen Department, 93 Ion Minulescu St., 031215 ,

Bucharest, Romania

Received: 21.02 .2020

Accepted: 19.03 .2020

https://doi.org/10.24264/Ifj.20.1.4

\section{STUDY ON THE CREEP BEHAVIOUR OF NAPPA UPPER PIG LEATHER}

ABSTRACT. From viewpoint of creep behavior, the visco-elasticity of nappa upper pig leathers is studied. A series model with three Kelvin models is proposed and has been used to imitate and describe their creep behavior successfully. The Kelvin model is a parallel connection model with a spring model and a dashpot model. The interrelated indexes of the imitation are favorable. It means that the imitation is reliable. KEY WORDS: nappa upper pig leathers, visco-elasticity, creep behaviour, Kelvin model

\section{STUDIU ASUPRA COMPORTAMENTULUI VISCO-ELASTIC AL PIELII DE PORC NAPPA PENTRU FETE ÎNCĂLTĂMINTE}

REZUMAT. Se studiază visco-elasticitatea pielii de porc nappa pentru fețe încălțăminte din punctul de vedere al comportamentului viscoelastic. Se propune o serie de trei modele Kelvin care se utilizează pentru a imita și descrie cu succes comportamentul visco-elastic. Modelul Kelvin este un model de conexiune paralelă cu un model tip arc și un model tip amortizor. Indicii inter-relaționați ai imitației sunt favorabili, ceea ce înseamnă că imitația este fiabilă.

CUVINTE CHEIE: piele de porc nappa pentru încălțăminte, visco-elasticitate, comportament visco-elastic, model Kelvin

\section{ETUDE SUR LE COMPORTEMENT AU FLUAGE DU CUIR PORCIN NAPPA POUR TIGES CHAUSSURES}

RÉSUMÉ. Du point de vue du comportement au fluage, la viscoélasticité des cuirs porcins nappa pour tiges chaussures est étudiée. Un modèle de série avec trois modèles Kelvin est proposé et a été utilisé pour imiter et décrire avec succès leur comportement de fluage. Le modèle Kelvin est un modèle de connexion parallèle avec un modèle de ressort et un modèle d'amortisseur. Les indices interdépendants de l'imitation sont favorables, ce qui signifie que l'imitation est fiable.

MOTS CLÉS : cuir porcin nappa pour tiges chaussures, viscoélasticité, comportement au fluage, modèle Kelvin 


\section{INTRODUCTION}

Visco-elasticity is a physical character that is between the characters of elastic solid and viscous fluid [1]. The visco-elastic behavior of synthetic polymers has been studied thoroughly [2]. These studies may fall into four such classes as stress relaxation, creep, sluggishness and internal consuming [2]. The study on the creep behavior of materials is to study the changing law of strain with the increase of creep duration at a constant stress [2].

Similar to other biological materials, the mechanical behaviors of leathers are very complicated. It depends on the duration of experiment, which means that leathers are visco-elastic materials [3]. The visco-elasticity of leathers is important for the comfortable feeling that leather goods may provide the consumers with and the shape-stability of leather goods. The study on the visco-elasticity of leathers is of great significance both in theory and in application. There are many factors that may affect the viscoelasticity of leathers. Kinds and origins of skins, processing technology, position and orientation of samples, temperature and humidity when the experiment is conducted may affect their viscoelasticity. However, a few studies have been reported in the field before [5].

Leathers are composed of cross networks of collagen protein fibers. There are holes in the collagen fiber network and between collagen molecules, which may vest leathers with good elasticity. Therefore, they are different from the continuous polymers [5]. It is considered that leathers are non-linear visco-elastic materials [6].

From the viewpoint of creep behavior, the visco-elasticity of nappa upper pig leathers is studied. A series model of three Kelvin models is proposed to imitate their creep behavior. The interrelated indexes of the imitation are favorable. It means that the imitation is reliable.

\section{Fundamental Theory}

Both spring models and dashpot models are usually used to study the visco-elasticity of materials. The mechanical behaviors of spring models follow the Hooke's elastic law and those of dashpot models follow the Newton's law for viscous fluid [2]. Neither the spring models nor the dashpot models can describe the mechanical behaviors of polymers successfully. So the mechanical behaviors of complicated polymers are located between those of both models.

The Kelvin model, which is a parallel connection of a spring and a dashpot, can describe the creep behavior of linear polymers successfully [2]. The relation between creep compliance $(J(t))$ and creep duration $(t)$ is according to Equation (1).

$J(t)=J(0)\left(1-e^{-\frac{t}{\tau}}\right)$

where $\tau$ is the postponing time, $\tau=\eta / E$ and $J$ is the creep compliance of the Kelvin model.

A series model of some Kelvin models can be used to describe the creep behavior of more complicated polymers. The relation between creep compliance $(\mathrm{J}(\mathrm{t}))$ and creep duration $(\mathrm{t})$ is according to Equation (2).

$$
\mathrm{J}(\mathrm{t})=\sum_{\mathrm{i}} \mathrm{J}_{\mathrm{i}}\left(1-\mathrm{e}^{-\frac{\mathrm{t}}{\tau_{\mathrm{i}}}}\right)
$$

where $\tau_{1}, \tau_{2}, \ldots, \tau_{n}$ are the postponing times of each Kelvin models, respectively, $\tau_{i}=\eta_{i} / E_{i}$, and $J_{1}$, $J_{2}, \ldots, J_{n}$ are the creep compliance of each Kelvin models, respectively.

Leathers are composed of cross networks of collagen protein fibers. There are differences among the bond length, bond angles, side groups, and chain fragments of collagen chains. The quality and cross length of each fiber bundles are different. There are soft fragments and hard fragments in the peptide chains. There are holes in the network and between collagen molecules, which vest leathers with good elasticity. Therefore, they are different from continuous polymers [5]. It is thought that leathers are nonlinear visco-elastic materials [6]. Their creep behaviors are rather complex. Only one Kelvin model cannot describe them successfully. A series of Kelvin models might be able to describe them successfully. 


\section{EXPERIMENTAL}

\section{Materials and Apparatus}

Nappa upper pig leather was provided by a local tannery, produced by the traditional process including soaking, degreasing, unhairing, liming, deliming, bating, pickling, chrome tanning, shaving, retanning, fatliquoring, drying, and finishing. Electronic Materials Testing Machine, WD-1, was from Jinan Zhongchuang testing Co. Ltd, China. Temperature and Humidity Conditioner was from Weifang Anke electronic Co. Ltd., China. Thickness Indicator, GJ9B1, was made by the Zhejiang Yuyao Machinery, China.

\section{Procedures}

The samples to be studied were from the center of nappa upper pig leathers. The average thickness $t(\mathrm{~mm})$ was determined and calculated. The cross-section area $A_{0}$ was obtained as $A_{0}=10 \mathrm{t} \times 10^{-6} \mathrm{~m}^{2}$ because the sample is $10 \mathrm{~mm}$ in width. The samples were placed in the temperature and humidity controller at $18^{\circ} \mathrm{C}, \mathrm{R} . \mathrm{H} .=65 \%$ for more than 48 hours to be air conditioned to reach equilibrium.

A sample was stretched to determine the tensile strength ( $\sigma \mathrm{max}$, the stress at break). Another sample was stretched to the stress of $\sigma_{0}=\sigma m a x / 2$. Its creep deformation $(\Delta \mathrm{L})$ was recorded with its stress unchanged. Its creep elongation $(\varepsilon)$ was obtained as $\varepsilon=\Delta \mathrm{L} / \mathrm{L}_{0} \times 100 \%$ and its creep compliance $(\mathrm{J}(\mathrm{t}))$ was calculated as $J(t)=\varepsilon / \sigma_{0}$.

The data processing was completed in computer with Gauss iteration program we had written before. The iteration formula was as equation (2).

\section{RESULTS AND DISCUSSION}

\section{Creep Behaviors of Nappa Upper Pig Leathers}

Figure 1 and Figure 2 show the relation between creepcompliance $J(t)$ and creep duration (t). It can be observed that the sample creep was very quick at the beginning of creep, which turned slow gradually. It could be concluded that there was at least one postponing time that is a few seconds in their postponing time spectrum. This part of creep was completed in a few seconds when the creep experiment began. Their minor creep postponing time means that shoes, or other leather goods, made from them will complete this part of creep when the shoes are dressed. The needs for comfortable feeling in the feet are met and it would be thought that the material (leather) from which the shoes were made is good. The creep compliance does not reach its equilibrium value in a short time, which means that shoes have good shape-stability.

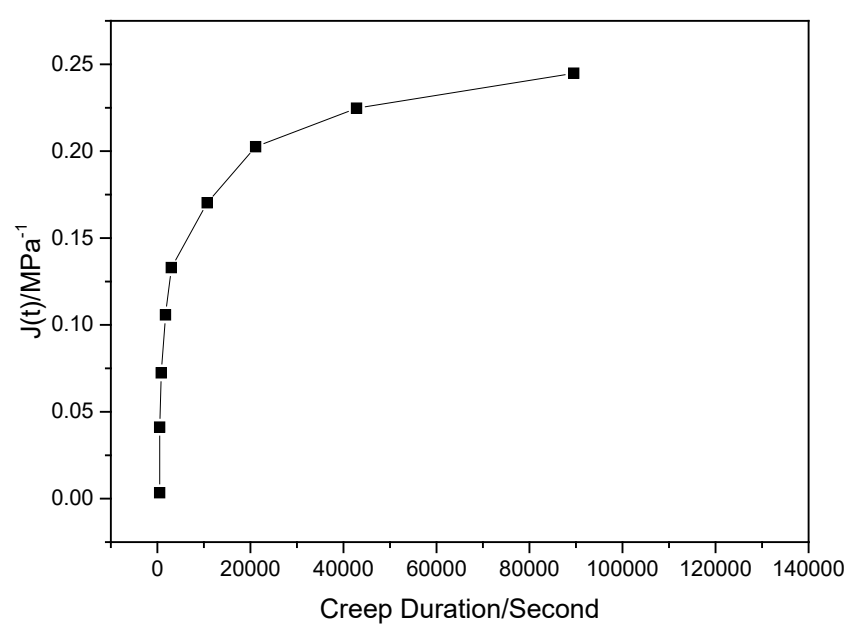

Figure 1. Creep compliance of sample perpendicular to the backbone vs. creep duration 


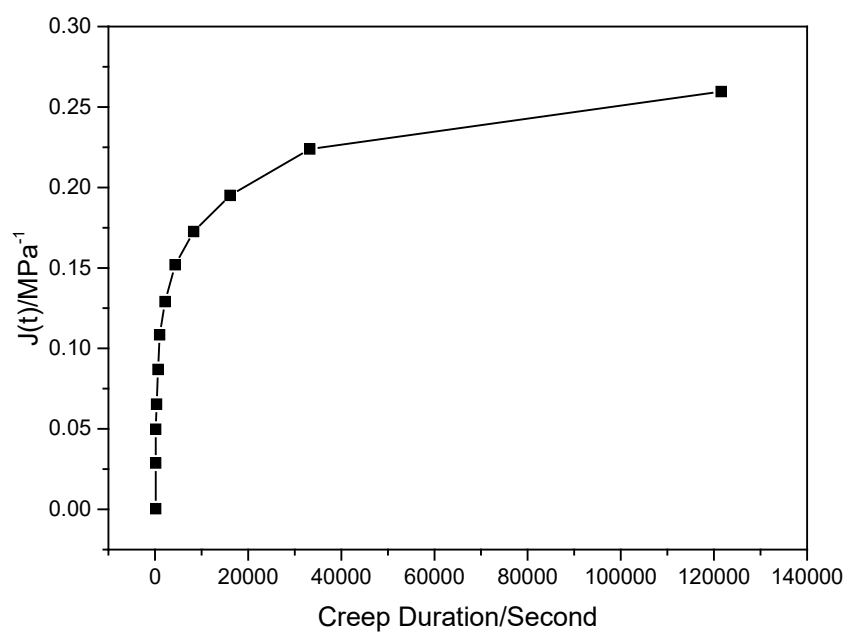

Figure 2. Creep compliance of sample parallel to the backbone vs. creep duration

\section{Model Imitation of Creep Behavior of Nappa Upper Pig Leathers}

The relation between creep compliance $\mathrm{J}(\mathrm{t})$ and creep duration was imitated with a series of some Kelvin models (equation 2). The imitation results were illustrated in Table 1 and Table 2 for samples of both perpendicular to and parallel to the backbone, respectively. It can be concluded that a series model of three Kelvin models may imitate their creep behavior successfully. The interrelated indexes of the imitation are 0.9971 and 0.9985 for the two samples, respectively. The creep behaviors of nappa upper pig leathers are close to this model. It means that the imitation is rather reliable.

Table 1: Measurement and calculation of creep compliance of sample perpendicular to the backbone

\begin{tabular}{ccccc}
\hline Order & $\begin{array}{c}\text { Creep } \\
\text { Duration (s) }\end{array}$ & $\begin{array}{c}\text { Measurement of Creep } \\
\text { Compliance }\left(\mathrm{MPa}^{-1}\right)\end{array}$ & $\begin{array}{c}\text { Calculation of Creep } \\
\text { Compliance }\left(\mathrm{MPa}^{-1}\right)\end{array}$ & Error \\
\hline 1 & 0 & 0.000 & 0.000 & 0.000 \\
2 & 25 & 0.008 & 0.010 & 0.002 \\
3 & 145 & 0.041 & 0.040 & -0.001 \\
4 & 445 & 0.073 & 0.073 & 0.00 \\
5 & 1045 & 0.105. & 0.106 & 0.001 \\
6 & 2455 & 0.138 & 0.137 & -0.001 \\
7 & 10030 & 0.170 & 0.172 & 0.002 \\
8 & 20830 & 0.203 & 0.200 & -0.003 \\
9 & 42430 & 0.225 & 0.228 & 0.002 \\
10 & 89030 & 0.245 & 0.245 & -0.002 \\
\hline
\end{tabular}

Table 2: Measurement and calculation of creep compliance of sample parallel to the backbone

\begin{tabular}{ccccc}
\hline Order & $\begin{array}{c}\text { Creep } \\
\text { Duration(s) }\end{array}$ & $\begin{array}{c}\text { Measurement of Creep } \\
\text { Compliance }\left(\mathrm{MPa}^{-1}\right)\end{array}$ & $\begin{array}{c}\text { Calculation of Creep } \\
\text { Compliance }\left(\mathrm{MPa}^{-1}\right)\end{array}$ & Error \\
\hline 1 & 0 & 0.000 & 0.000 & 0.000 \\
2 & 10 & 0.029 & 0.029 & 0.000 \\
3 & 165 & 0.065 & 0.068 & 0.003 \\
4 & 365 & 0.086 & 0.082 & -0.004 \\
5 & 873 & 0.108 & 0.106 & -0.002 \\
6 & 1983 & 0.129 & 0.133 & 0.004 \\
7 & 4215 & 0.151 & 0.152 & 0.001 \\
8 & 8160 & 0.172 & 0.168 & -0.004 \\
9 & 15960 & 0.194 & 0.192 & -0.002 \\
10 & 33220 & 0.223 & 0.225 & 0.002 \\
11 & 121420 & 0.258 & 0.258 & 0.000 \\
\hline
\end{tabular}




\section{Rheological Constants of the Model}

The rheological constants of the model are illustrated in Table 3. It is indicated that the relation among creep compliance of each Kelvin models is as $\mathrm{J}_{1}<\mathrm{J}_{2}<\mathrm{J}_{3}$. The differences among them are very small.

Table 3: Rheological constants of the creep model

\begin{tabular}{ccccccc}
\hline Rheological constants & $J_{1}\left(\mathrm{MPa}^{-1}\right)$ & $\tau_{1}(\mathrm{~s})$ & $\mathrm{J}_{2}\left(\mathrm{MPa}^{-1}\right)$ & $\tau_{2}(\mathrm{~s})$ & $\mathrm{J}_{3}\left(\mathrm{MPa}^{-1}\right)$ & $\tau_{3}(\mathrm{~s})$ \\
\hline$\perp$ & 0.0329 & 108.6 & 0.0985 & 897.9 & 0.1134 & 22637.1 \\
$\|$ & 0.0549 & 14.14 & 0.0787 & 956.12 & 0.1248 & 25033.2
\end{tabular}

Where $\perp$ and $\|$ are samples perpendicular to and parallel to the backbone, respectively

It can be calculated that the creep compliance at the beginning of creep $(t=0)$ is 0 . When the creep duration $t=\infty$, the creep compliance of samples studied are 0.2448 and 0.2584 , respectively. This might be the reason why leather shoes become larger and larger with the increase of dressing duration to fit the shape of the feet.

The relation among postponing times of each Kelvin models is as $\tau_{1}<\tau_{2}<\tau_{3}$. The differences among postponing times of each Kelvin models are considerable. For example, $\tau_{3}$ is about 200 times of $\tau_{1}$. It is to say that the creep time distributes in a rather wide range. The first creep time $\left(\tau_{1}\right)$ of both samples are a few seconds, which means that the creep starts at the beginning of the experiment. It corresponds to the results in Figure 1 and Figure 2. The contribution to the total creep at the first few seconds of experiment is mostly from the first Kelvin model. It is demonstrated clearly that the cross networks of the collagen fibers are rather complicated.

The contribution of each Kelvin models to the total creep compliance is different in different creep period. Let's suppose that the creep compliance of the $\mathrm{i}$-th Kelvin model is $\mathrm{J}_{\text {i }}$ and its postponing time is $\tau_{\text {. }}$. The contribution of this Kelvin model to the total creep compliance is according to equation (2).

When $t$ is much less than $\tau_{i}, J_{i}(t)=0$. It indicates that no contribution is given by the $i$-th Kelvin model to the total creep.

When $t \approx \tau_{i}, J_{i}(t)$ increases with the increase of creep duration obviously. Since the difference among postponing times of each Kelvin models is considerable, the change of the total creep compliance at different period is mainly from different Kelvin models.
When $t$ much more than $\tau_{i}, J_{i}(t)=J_{i}$. It is a constant, which means that the contribution of the i-th Kelvin model to the total creep is constant and does not change with the increase of creep duration any more.

The creep rheological constants of samples perpendicular to and parallel to the backbone are different. It indicates that nappa upper pig leathers are anisotropy materials. Although the creep behaviors of the two samples are different, their creep law is the same.

\section{CONCLUSION}

Nappa upper pig leathers behave viscoelasticity in creep behavior. A series model of three Kelvin models may describe their creep behaviors successfully. The interrelated indexes of the imitation are favorable, which indicates that the imitation is reliable. The comfortable feeling given to the consumers and the shapestability of leather goods when their goods are dressed may be described with the creep rheological constants of the model.

\section{Acknowledgments}

The financial supports of this work from the National Natural Science Foundation Commission of China (No. 51673177, 51373097) and National Key R \& D Program (No. 2017YFB0308500) are greatly appreciated.

\section{REFERENCES}

1. Tang, K., Zhang, C., Wang, F., Wu, D., Study on the stress-relaxation behaviour of nappa upper pig leather, J Soc Leath Tech Ch, 2008, $92,6,262-266$. 
2. Chinese University of Science and Technology, The Structure and Properties of Polymers, Beijing, Science Publishing House, 1983.

3. Huang, J., Liu, J., Tang, K., Yang, P., Fan, X., Wang, F., Du, J., Liu, C., Effect of Cyclic Stress while Being Dried on the Mechanical Properties and Thermostability of Leathers, J Am Leather Chem As, 2018, 113, 10, 318325.

4. Attenburrow, G.E., Wright, D.M., Studies of the mechanical behavior of partially processed leather, J Am Leather Chem As, 1994, 89, 12, 391.

5. Tang, K., Zheng, X., Li, W., Casadonte, D.J., Modification of polyurethane finishing agent using collagen hydrolysate from chrome shavings, J Am Leather Chem As, 2010, 105, 1, 25-31.
6. Komanowsky, M., Cooke, P.H., Damert, W.C., Kronick, P.L., McClintick, M.D., Stressrelaxation behavior of leather, J Am Leather Chem As, 1995, 90, 243-256.

7. Chengdu University of Science and Technology and Xibei Light Industry College, Physical and Chemical Analysis of Leathers, Beijing, Light Industry Publishing House, 1988.

8. Aklonis, J.J., Macknight, W.J., Introduction to Polymer Viscoelasticity, J. Wiley and Sons, New York, 1983.

(C) 2020 by the author(s). Published by INCDTPICPI, Bucharest, RO. This is an open access article distributed under the terms and conditions of the Creative Commons Attribution license (http:// creativecommons.org/licenses/by/4.0/). 